\title{
First lines on a Comparative Study of the Theoretical Foundations of Judicial Deference
}

Ricardo Perlingeiro

Estácio de Sá University, Brazil.

This piece can be considered as the preliminary results of the research that is being conducted under the project named 'Comparative Study of the Theoretical Foundations of Judicial Deference' which is developed by the Post-Graduate Law Program of the University Estácio de Sá / PPGD-Unesa (with support of the Post-Graduate Administrative Justice Program of the Fluminense Federal University / PPGJA-UFF) in partnership with Birmingham University's Centre for American Legal Studies, including among its activities the joint organization of two seminars and a future publication of a book. This project

It is a collection of expanded abstracts adapted from the lectures given in a number of different events that took place either in Brazil, in the USA and the UK, gathering the members of this network, as following: 1) seminar "Comparative Study of the Theoretical Foundations of Judicial Deference" held in Rio de Janeiro on September 3, 2018 as part of the Post-Graduate Law Program of the Estácio de Sá University / PPGD-Unesa, 2) the roundtable "Comparative Study of the Theoretical Foundations of Judicial Deference", organized by the Law and Society Association's collaborative research network "Comparative Constitutional Law and Legal Culture: Asia and the Americas", at the 2019 Annual Meeting of the Law and Society Association, on 30 June 2019, in Washington, D.C., and 3) the roundtable "The Judiciary and the Administrative State" as part of the seminar "Global Constitutional Dialogue: Judicial Challenges for the $21^{\text {st }}$ Century" held at Birmingham City University, in Birmingham, UK, on 4 September 2019. All the above-mentioned events were carried out in the framework of the research project "The "Comparative Study of the Theoretical Foundations of Judicial Deference", carried out by the Centre for American Legal Studies (The School of Law, Birmingham City University - BCU) jointly with the Post-Graduate Law Program of the Estácio de Sá University / PPGD-Unesa, under the coordination of the professors Ricardo Perlingeiro (Unesa) and Anne Oakes (BCU). 
JUDICIAL DEFERENCE \& THE ADMINISTRATION:

Are UK/US parallels feasible?

Anne Oakes*

Birmingham City University, United Kingdom

\section{I. “CONSTRUCTIVE AMBIGUITY OVER CONCEPTUAL CLARITY?”:}

A very british constitutional fudge.

In Chevron v. Natural Resources Defense Council (1984), the United States Supreme Court articulated an administrative law principle that requires federal courts to defer to a federal agency's interpretation of an ambiguous or unclear statute that Congress delegated to the agency to administer. ${ }^{1}$ As practised in the U.S. the principle reflects two assumptions a) that the administrative state has value in contemporary society and $b$ ) for that reason it is appropriate to concede to administrative officials a measure of legitimate authority to interpret the law that they administer, with the consequence that judges should not interfere with an administrative decision merely because they disagree with its substance. Although current critics of the former assumption include President Trump who has secured the appointment to the Supreme Court of two justices known to disfavour the growth of the modern administrative state, the doctrine is widely regarded as one of the fundamental underpinnings of the modern administrative state and is unlikely to be reversed in the immediate future although its scope may conceivably be limited. However, it is important to remember that the formal justification for judicial deference to administrative interpretations is found in the power of Congress to delegate interpretive

\footnotetext{
* Dr Anne Richardson Oakes is an Associate Professor of American Legal Studies in Birmingham City University's School of Law. She is Director of the Centre for American Legal Studies and currently teaches US Constitutional Law and Research Methods. She is also a member of the Society of Legal Scholars.

${ }^{1}$ Chevron U.S.A., Inc. v. Natural Resources Defense Council, Inc., 467 U.S. 837 (1984).
} 
authority to the executive, either expressly or by implication. ${ }^{2}$ In other words, Chevron deference reflects a constitutional structure of separation and diffusion of power which gives rise to complex power-sharing arrangements whereby both legislative and executive powers can be shared between Congress and the President ${ }^{3}$ and the judicial obligation is to "serve as a "check" on the political branches". 4

In this paper I want to explain why Chevron deference has no equivalent in the U.K. and to do so by addressing the issue of the theoretical basis for judicial review in U.K. constitutional arrangements. The paper will make the following assertions:

There is a doctrinal tension between the two British primary constitutional doctrines, the Sovereignty of Parliament and the Rule of Law, the effect of which it to lock them into "a zero-sum contest for supremacy within the constitutional order." ${ }^{5}$ The doctrines are Dicey's "twin constitutional pillars" the doctrine of Parliamentary Sovereignty which accords unlimited and undivided competence to acts of the legislature, and the doctrine of the Rule of Law which provides the justification for the judicial practice of administrative, (but not legislative) review. The tension arises because doctrinally the judiciary derives its powers from the will of Parliament but uses common law principles of interpretation in a way that can limit and even subvert that will, thereby positing the challenge of an additional source of authority that constitutional orthodoxy cannot explain.

Particularly notable in this connection is the House of Lords decision in Anisminic v. Foreign Compensation Commission ${ }^{6}$ that an express ouster clause did not preclude judicial review despite the clear wording of the statute to the contrary. The case eroded the distinction

\footnotetext{
2 Peter Cane, Controlling Administrative Power: An Historical Comparison, 214 (2016). See United States v. Mead Corp., 533 U.S. 218 (2001).

${ }^{3}$ As Cane points out: just as the power of veto gives the President a share of legislative power, Congress's general power - to 'make all Laws which shall be necessary and proper for carrying into Execution' its specific legislative powers 'and all other Powers vested by the Constitution in the Government of the United States, or in any Department of officer thereof' gives it a share in implementation of the law. Cane, supra note 2, at 78.

${ }^{4}$ See Perez v. Mortg. Bankers Ass'n, 135 S. Ct. 1199, 1217 (2015) (Thomas, J., concurring in judgment): [The Seminole Rock line of precedents] raises two related constitutional concerns. It represents a transfer of judicial power to the Executive Branch, and it amounts to an erosion of the judicial obligation to serve as a "check" on the political branches.

${ }^{5}$ Matthew Lewans, Administrative Law and Judicial Deference, 14 (2018).

${ }^{6}$ Anisminic Ltd. v. Foreign Compensation Commission [1969] 2 AC 147 (HL). Anisminic has been extensively considered by the U.K. Supreme Court in R. (Privacy International) v. Investigatory Powers Tribunal [2019] UKSC 22. For comment see M. Gordon, Privacy international, parliamentary sovereignty and the synthetic Constitution, U.K. CONST. L. BLOG (Jun. 26, 2019).
} 
between errors that administrative authorities have power to make and those which they do not, thereby representing a major judicial "power grab" and a significant challenge to the orthodox view that the only basis for judicial interference with administrative action was the doctrine of ultra vires, i.e. the idea that the authority was acting outside the scope of the powers conferred by Parliament.

Since then, the theoretical basis for the exercise of judicial review in the U.K. has been the subject of an extensive debate which has taken place at both academic and judicial levels. The debate has polarised around "weak" and "strong" challenges to the constitutional orthodoxy. ${ }^{7}$ The "weak" challenge reconciles the twin doctrines via the fiction of implied legislative intent, i.e. Parliament is presumed to legislate on the basis that the authority that it confers will be subject to "policing" by the judiciary in accordance with principles that are indeed judicially created. On this view, to the extent that they have not been legislatively reversed, these common law principles must be regarded as having the implied sanction of parliamentary authority. It is fair to say that this is the view that generally has judicial support. However it is also true to say that it represents, in the words of Professor Mark Elliot, the "constructive ambiguity over conceptual clarity" that characterises so much of our British constitutionalism. ${ }^{8}$

The "strong" challenge comes from proponents of "common-law constitutionalism" i.e. the view that the bedrock of British constitutionalism is to be found in a matrix of common law principles which operate to both define and constrain the outer limits of Parliamentary Sovereignty. References in recent Supreme Court decisions ${ }^{9}$ to "common law rights" which are not dependent upon the European Convention of Human Rights fit into this constitutional model and provide support for an activist judicial role but the underlying challenge to constitutional orthodoxy remains deeply contentious.

The second assertion concerns the ambit of judicial discretion. The common law principles of review reflect an assumption that the judicial role is that of "policing the boundaries" of parliamentary authority. This translates into a requirement that public authorities

\footnotetext{
${ }^{7}$ See Lori Ringhand, Fig leaves, fairy tales and constitutional foundations: Debating judicial review in Britain, 43 Colum. J. TRANSNAT'L L. 865, 879 (2005).

${ }^{8}$ Mark C. Elliott, Sovereignty, primacy and the common law constitution: What has EU membership taught us?, in The UK CONSTITUTION AFTER MiLleR: BREXIT AND BEYOND (Mark Elliott et al., eds. 2018).

${ }^{9}$ See, e.g. Kennedy v. Charity Cmm'n. (2014) UKSC 20.
} 
stay "within the four corners" of the authority conferred by parliament ${ }^{10}$ and the extent that they do so is a matter for the judiciary to determine. This means that, although considerations of justiciability, separation of powers and respect for administrative expertise do clearly influence judicial decision-making, and dictate "deference in practice" in appropriate cases, there is no general recognition in our constitutional arrangements of agency or administrative interpretive competence that could sustain an equivalent of Chevron deference. The result in many, if not most, cases is quite the reverse. The ambit of discretion given to our judiciary by these common law principles of review is so very wide that however much our judiciary warn themselves against usurping the authority that Parliament has given not to them but to the minister or agency whose decision is in question, they are inevitably vulnerable to the accusation that their decision-making is little more than a rationalisation of their perceptions of the merits of the issue in front of them. In other words, the charge is that the stated judicial task of interpreting the will of parliament is nothing more than a "fig-leaf" for disguising the otherwise naked exercise of judicial power. ${ }^{11}$

In conclusion, this paper considers another assertion, namely that the fact that public law scholarship has broadly focussed on the limits and boundaries of administrative power reflects an outdated view of the value of the administrative state in the lives of its citizens. If this is indeed the case, this paper now asks what if anything can be learnt from U.S./Canadian concepts of "deference" and considers the suggestion that administrative officials could be entrusted with legitimate interpretive authority such as to justify a doctrine of judicial deference if "they have been legally empowered by a democratically responsible branch of government to decide a question of law on behalf of the community, and their decision coveys concern and respect for persons affected by their decision in both a procedural and substantive sense". ${ }^{12}$

\footnotetext{
${ }^{10}$ As explained by Lord Greene in Associated Provincial Picture Houses v. Wednesbury Corporation (1948) 1 KB 223.

${ }^{11}$ See Sir John Laws, Law and democracy, Public Law 72, 78-9 (1995): In the elaboration of [principles of judicial review] the courts have imposed and enforced judicially created standards of public behaviour ... [T]heir existence cannot be derived from the simple requirement that public bodies must be kept to the limits of their authority given by Parliament. Neither deductive logic nor the canons of ordinary language ... can attribute them to that ideal, since ... in principle their roots have grown from another seed altogether ... They are, categorically, judicial creations. They owe neither their existence nor their acceptance to the will of the legislature. They have nothing to do with the intention of Parliament, save as a fig-leaf to cover their true origins. We do not need that fig-leaf anymore...

${ }^{12} I d$. at 221.
} 


\section{REFERENCE LIST}

J. Laws, Law and democracy, PUBLIC LAW 72-93 (1995).

L. Ringhand, Fig leaves, fairy tales and constitutional foundations: Debating judicial review in Britain, 43 COLUM. J. TRANSNAT'L L. 865-904 (2005).

M. Gordon, Privacy international, parliamentary sovereignty and the synthetic Constitution, U.K. CONST. L. BlOG (Jun. 26, 2019), https://bit.ly/2ytfFzt/.

M. C. Elliott, Sovereignty, primacy and the common law constitution: What has EU membership taught us?, in THE UK CONSTITUTION AFTER MILlER: BREXIT AND BEYOND (Mark Elliott et al., eds. 2018).

M. LEWANS, AdMiniSTRATIVE LAW AND JUdiCIAL DEFERENCE (2018).

P. CANe, Controlling Administrative Power: An Historical COMPARison (2016).

\section{CASES}

Court of Appeal Of England And Wales, Associated Provincial Picture Houses v. Wednesbury Corporation (1948) 1 KB 223.

House of Lords, Anisminic Ltd. v. Foreign Compensation Commission [1969] 2 AC 147 (HL).

U.K. Supreme Court, Kennedy v. Charity Cmm'n. (2014) UKSC 20.

U.K. Supreme Court, R. (Privacy International) v. Investigatory Powers Tribunal [2019] UKSC 22.

U.S. Supreme Court, Chevron U.S.A., Inc. v. Natural Resources Defense Council, Inc., 467 U.S. 837 (1984).

U.S. Supreme Court, Perez v. Mortg. Bankers Ass'n, 135 S. Ct. 1199, 1217 (2015).

U.S. Supreme Court, United States v. Mead Corp., 533 U.S. 218 (2001). 


\title{
JUDICIAL DEFERENCE IN BRAZIL AND IN THE UNITED STATES OF AMERICA: A comparative overview
}

\author{
Fernanda Duarte* \\ Estácio de Sá University, Brazil \\ Rafael Mario Iorio Filho** \\ Estácio de Sá University, Brazil
}

As part of our research interest, applying the semiolinguistic methodology of discourse analysis and the method of comparison by difference, the latter borrowed from Antropology, we aim to provide a description of native and /or theoretical categories of the Brazilian legal culture in contrast with American legal culture, in order illuminate the idea that legal systems cannot be translated or verted straightforwardly as if it were a mere lexicon translation challenge. There is much more about it that relates to meaning and understanding that surpass the linguistic problem. That is what we intend to convey with our effort. On this presentation we will describe the Brazilian system whereas our colleague Prof. Ritchie will deal with the US model. So, the goal of both presentations is to discuss the different approach to judicial deference in Brazil's and the United State's legal systems - here considered as a cultural endeavor - taken by each country's Supreme Court.

It is necessary to say that we consider legal culture here as a very broad range category that tries to explain or describe how people in various historical and cultural contexts construct the meaning of law and how they use it in everyday life.

Our theoretical framework is basically arranged according to three sets of ideas: 1) the understanding of law as a set of local discourses and practices; 2) the utility of the theoretical 
category "legal sensibilities" by Clifford Geertz ${ }^{13}$; 3) the recognition that culture interferes in socialization and social efficacy of Law when people translate legal categories.

The importance of this framework is that it leads us to the place of social relations and its web of meanings, helping us to appreciate the extent of the practices, rituals, and representations that directly impact law.

Thus, we allow ourselves to think that law is a cultural product, despite its universalist normative nature. If law can be taken as a branch of knowledge it must be interpreted in light of the "local knowledge". And this can work as a key concept to prevent uncritical transplantations of legal categories that ultimately are "misplaced" with low capacity to interfere with reality shaping people's behaviors.

In Brazil, especially from the argumentative point of view, this issue is a little shady because the possibility of judicial review of the discretionary administrative act swings between different ideas that go from a very narrow position that embodies a large degree of deference to broader ones that allow judges to re-evaluate the administrative act.

This variety does not allow the possibility of establishing standards of scrutiny (as it happens in the U.S. system, when the Supreme Court deals with equal protection claims, for instance). And all of them are used by the Supreme Court, as well as lowest courts to a certain extent. So there is no prevailing doctrine on the subject. And how can one know beforehand what is the prevailing position? The answer is simple: one cannot.

The narrowest position states that discretion implies a choice that can only be made by the executive agents, but if it is found a misuse of power, the Judiciary has the authority to exam

\footnotetext{
* PhD in Law. Professor of the Postgraduate Program in Law at Estácio de Sá University. Coordinator of CRN01 / LSA. Coordinator of the Center for Studies on Law, Citizenship, Process and Discourse / NEDCPD-PPGD / UNESA. Associate Professor at Fluminense Federal University / Faculty of Law. Researcher at NEPEAC / INCTInEAC - Institute for Comparative Studies in Institutional Conflict Management / PROPPi / UFF. Email: fduarte1969@yahoo.com.br

**PhD in Law. Professor of the Postgraduate Program in Law at Estácio de Sá University. Coordinator of the Center for Studies on Law, Citizenship, Process and Discourse / NEDCPD-PPGD / UNESA. CRN01 / LSA Coordinator. Professor at Fluminense Federal University / Faculty of Law. Researcher at NEPEAC / INCT-InEAC - Institute for Comparative Studies in Institutional Conflict Management / PROPPi / UFF. Email: rafa.ioriofilho@gmail.com

${ }^{13}$ Clifford Geertz, Local Knowledge: Further Essays in Interpretive Anthropology (Basic Books, 1983).
} 
the choice that was made in deviation of its objective, as we can see in STF, AI-AgR/BA 594.955-1 (DJU Aug. 03, 2007), for instance.

On the other hand, the broader holdings state that the Judicial Branch has the duty to see if the constitutional principles were observed by the executive agents, as we can see in STF, ACO 876 MC-AgR/BA (DJU Aug. 01, 2008) and STF, ADPF 101/DF (DJU June 04, 2012).

Or we can call attention to STF, ADPF 378 MC/DF (DJU Mar. 08, 2016) when the Court has examined if the proceedings to impeach the President of the Republic under Law $1079 / 1950$ were legitimate, if the legal text was interpreted appropriately, in the light of the current Constitution.

Actually, some authors have even listed a different range of positions taken by the court. In a study of 2015, França ${ }^{14}$ has listed five situations:

1. The syndicability of administrative merit is not simply accepted. ${ }^{15}$

2. The Court uses control of administrative merit when it comes to mere control of legality. ${ }^{16}$

3. A control of the indirect administrative merit is made, without assuming frontally that it accomplishes it, trying to preserve the maximum of the constitutional principles, by means of an exercise of ponderation of involved values. ${ }^{17}$

4. The control of administrative merit is accepted on a regular basis and in exceptional cases. ${ }^{18}$

5. The control of administrative merit is removed because of the inadequacy of the procedural means used in the exercise of the jurisdictional claim. ${ }^{19}$

\footnotetext{
${ }^{14}$ Gil França, O controle dos atos administrativos e a jurisprudência do STJ e do STF. EMPÓRIO DO DIREITO (Sept. 24, 2015).

${ }^{15}$ STF, AgR in RE 480.107 (DJe Mar. 27, 2009).

${ }^{16}$ STF, HC 82.893/SP (DJ Apr. 08, 2005).

${ }^{17}$ STF, AI 509.213 in AgR/AL (DJ Dec. 16, 2005); STF, RMS 24.823/DF (DJ May 19, 2006).

${ }^{18}$ STF, RMS 24.699/DF (DJ July 01, 2005).

${ }^{19} \mathrm{STF}, \mathrm{Ag}$ in RE 505.439/MA (DJe Aug. 28, 2008).
} 
And even some Brazilian Justices, who are called Ministros, in some of the cases decided by the Court, can adopted more than one position regarding the possibility of judicial review of administrative acts which will have an impact in the way judicial deference is perceived as well.

In a way, from these cases we can see a lack of a standardization awareness by the Brazilian Supreme Court (which one might say is one of the features of Brazil's legal system). And this turns the subject of judicial deference even more problematic once predictability is not a card we can play easily or safely.

And we can say that the meaning and uses of judicial deference differ radically between the Brazilian and U.S. legal cultures. The two Supreme Courts view separation of powers, constitutional supremacy, the role of the judiciary, and the use of discretion very differently. In short, the Brazilian Supreme Court is led by the motto "We know better!" while the U.S. Supreme Court might respond "You decide!".

\section{REFERENCE LIST}

A. S. de M. Godoy, Direito administrativo nos EUA preserva poder público. REVISTA CONSUlTOR JURÍDICO (June 07, 2011), https://www.conjur.com.br/2011-jun-07/nao-direitoabsoluto-acao-administracao-eua?pagina=3.

C. Tácito, Presença norte-americana no direito administrativo brasileiro, 129 REVISTA DE DIREITO ADMINISTRATIVO RDA, 21-33, (July/Sept. 1977) http://bibliotecadigital.fgv.br/ojs/index.php/rda/article/view/42480/41199.

C. GEERTZ, LOCAL KNOWLEDGE: FurThER ESSAYS IN INTERPRETIVE ANTHROPOLOGY (Basic Books, 1983).

G. França, $O$ controle dos atos administrativos e a jurisprudência do STJ e do STF. EMPÓRIO DO DIREITO (Sept. 24, 2015), http://emporiododireito.com.br/leitura/o-controle-dos-atosadministrativos-e-a-jurisprudencia-do-stj-e-do-stf.

H. Berman, Law and Revolution: The Formation of the Western Legal Tradition (Harvad University Press, 1983). 
R. C. R. Oliveira, O Modelo Norte-Americano de Agências Reguladoras e sua Recepção pelo Direito Brasileiro. 12 REVISTA DA EMERJ, (47) 157-176 (2009) http://www.emerj.tjrj.jus.br/revistaemerj_online/edicoes/revista47/Revista47_157.pdf

\section{CASES}

Supremo Tribunal Federal (STF), AI-AgR/BA 594.955-1 (DJU Aug. 03, 2007).

STF, HC 82.893/SP (DJ Apr. 08, 2005).

STF, RMS 24.699/DF (DJ July 01, 2005).

STF, AI 509.213 in AgR/AL (DJ Dec. 16, 2005).

STF, RMS 24.823/DF (DJ May 19, 2006).

STF, ACO 876 MC-AgR/BA (DJU Aug. 01, 2008).

STF, AgR in RE 480.107 (DJe Mar. 27, 2009).

STF, ADPF 101/DF (DJU June 04, 2012).

STF, ADPF 378 MC/DF (DJU Mar. 08, 2016).

STF, Ag in RE 505.439/MA (DJe 28 Aug. 28, 2008) 


\title{
JUDICIAL DEFERENCE OR JUDICIAL ACTIVISM:
}

\author{
An exploration of Dutch Administrative Law
}

Friso Johannes Jansen*

Birmingham City University, United Kingdom

\section{INTRODUCTION}

This paper seeks to examine to what extent and in which ways the Dutch administrative law allows for mechanisms that promote deference to the interpretation of facts and law by the executive branch. A particular focus is placed on two elements: the objection procedure and the general principles of good administration.

\section{JUDICIAL DEFERENCE OR JUDICIAL ACTIVISM:}

A theoretical assessment from a Dutch Administrative Law perspective

Important is that the court is only open for those that have followed an objection procedure, which takes places within the administrative body that took the primary decision. ${ }^{20}$ It is always the decision that is taken after the objection procedure, which can then be appealed. The review of decision in an objection procedure is described as full, both the law and policy that led to the decision can be reviewed in full by the administrative decision-maker that can

\footnotetext{
* Dr Friso Johannes Jansen is a Senior Lecturer in Law at BCU. He is the module leader for Public Law on the PGDL programme. He is also responsible for the LLB Module on Medical Law \& Ethics and LLM module on Global Health Law.

${ }^{20}$ Article 7:1 General Administrative Law Act.
} 
substitute any decision it wishes for the original one. ${ }^{21}$ This objection procedure filters out around $90 \%$ of all contested decisions. ${ }^{22}$

The Administrative Law Act provides the courts with a range of procedural tools to challenge decision-making, for example the requirement to carefully establish the facts. The court through the prism of "uncertainty about the facts" can steer the decision-making in a certain direction and restrict the discretion of the executive by finding the "uncertainty about the facts" unlawful.

Extensive empirical research into the use of the objection procedure and the use of appeal to the courts will be evaluated with an eye to establishing whether there is a correlation between the amount of judicial deference (or activism) and willingness to litigate. ${ }^{23}$ The reasons people litigate do not only correlate with the procedural quality of the decision but also rely on notions of fairness and procedural justice. ${ }^{24}$ Rather, it seems plausible, that increase or decrease of the accessibility of the courts, through increase or decrease of court fees has a much greater effect on the amount of litigation. ${ }^{25}$

\section{An Overview Of The SCRutiny Of Decisions Of The EXECUTIVE Within Dutch}

\section{ADMINISTRATIVE LAW}

The administrative law courts operate within a framework of rules that determine to what extent they are able to scrutinize the decisions of the executive. Under the Dutch General Administrative Law Act decisions of the executive have to conform to the general principles of

\footnotetext{
${ }^{21}$ A.T. MARSEILLE et al., BestuURSRECht 2, 173 (6th ed. 2016).

22 J.G. van Erp \& C.M. Klein Haarhuis, De FILTERWERKING VAN BUITENGERECHTELIJKE PROCEDURES (Cahier 2006-6, WODC 2006).

${ }^{23}$ Among many: A.T. Marseille \& I.M. Boekema, Administrative decision-making in reaction to a Court judgment can the administrative judge guide the decision-making process?, 9 UTRECHT LAW REVIEW (3) 51 (2013); Bert Marseille et al., Hoger beroep in het bestuursrecht: massaal gebruik, ontevreden gebruikers, 38 RECHT DER WERKELIJKHEID (2) 76 (2017); Marc Wever \& Albert T. Marseille, Neutrality and the Dutch objection procedure, 15 International Public Administration Review 107 (2018); Kars J. de Graaf \& Albert T. Marseille, On administrative adjudication, administrative justice and public trust. Analyzing developments on access to justice in Dutch Administrative law and its application in practice, in ON LAWMAKING AND PUBLIC TRUST (S. Comtois \& K. J. de Graaf 2016); K.J. de Graaf et al., Administrative decision-making and legal quality: An introduction, in Quality of Decision-MaKing in Public Law 11 (K.J. de Graaf; J.H. Jans; A.T. Marseille; J. de Ridder 2007); I.M. BOEKEMA, DE STAP NAAR HOGER BEROEP (2015).

${ }^{24}$ Tom R. Tyler, Why People Obey the Law (2006); I.M. Boekema, De Stap nAar hoger beroep (2015).

${ }^{25}$ Which is a point that will be further developed in the chapter.
} 
good administration. These principles include the duty to give reasons the duty of a balanced and reasonable weighing of interests the duty to gather the relevant facts. ${ }^{26}$ In addition, the executive has to varying degrees room to control the meaning of the law and the interpretation of fact which can be described on a scale using the concepts of decision space which is the overarching concept describing the room the executive has in determining the meaning of the law, establishing the facts, interpreting the facts and weighing of all the relevant interests. ${ }^{27}$ This concept is often broken down into "evaluative freedom" which is the freedom for the executive to determine whether the requirements for the exercise of a given power have been met and "policy freedom" which is the power of the executive to weigh various interests and to choose whether to exercise the power or not. ${ }^{28}$ Where the courts control the meaning of the law and the establishment of facts, when it comes to interpreting these facts and weighing of interests the courts show deference to the executive. The operationalization of these concepts and its use within Dutch Administrative Law will be discussed using a recent controversial decisions to provide a good illustration of the increasing intensity (and less deference) with which decisions of the executive are scrutinized by the court.

\section{GAS EXTRACTION AND EARTHQUAKES IN GRONINGEN}

This case concerns the extraction of gas for use by industry and consumers from the Slochterenveld, one of the largest gas reservoir in Europe, in Groningen which is a province in the North of the Netherlands. The case concerned the decision by the Minister for Economic Affairs to allow the NAM, the Dutch Petroleum Company who has a licence to extract the gas, to extract 21.6 billion $\mathrm{m} 3$ of Gas during the period of 1 year. ${ }^{29}$ The Dutch Council of State decided to quash this decision but maintain gas extraction at 21.6 billion $\mathrm{m} 3$ for a year so that the Minister for Economic Affairs could take a new decision.

\footnotetext{
${ }^{26}$ H.E. Bröring et al., BESTUURSRECHT 1, at 280 (5th ed. 2016).

${ }^{27} I d$. at 289.

${ }^{28}$ Id..at 289

${ }^{29}$ Administrative Jurisdiction Division of the Council of State, ECLI:NL:RVS:2017:3156 (Nov. 15, 2017).
} 
It is interesting to examine in detail how the Council of State evaluated the scientific reports used to justify the decision by the minister to permit a certain level of extraction of Gas. The Council of State performs a detailed scrutiny of these reports. The court motivates this intensive level of scrutiny by referring to the potential infringement of the right to life as a result of the earthquakes that are caused by the extraction of the gas. ${ }^{30}$ The court than orders that the current level will be maintained until a new decision has been taken. ${ }^{31}$ This fits in with a wider trend within Administrative Law for courts, in line with the wishes of the legislator, to promote finality of decision-making. Recently the minister decided to stop extracting gas completely from 2030, a seismic shift in Dutch energy policy. ${ }^{32}$

\section{URGENDA AND THE PROBLEM OF CLIMATE CHANGE}

This case, which was based on a private law action based on an unlawful act considered the obligations under the various climate treaties the Dutch state is party to and resulted in an order for the Dutch state to reduce Carbon Emissions by $25 \%$ based on the level of $1999 .{ }^{33}$ The main legal device the court used was a duty of care. ${ }^{34}$ This duty of care was established by the court with reference to a large body of international treaties and reports from the IPCC. The novel use of the long existing concept of duty of care to mandate the state to reduce greenhouse gas emission to protect its population against the harmful effects of climate change deserves scrutiny as this has the potential to be employed in a wider context and in many different countries. The principle was first fully articulated in the 'basement-hatch judgement' ${ }^{35}$ and the court uses the most recent climate science to articulate an unwritten duty of care that needs to be satisfied as to not commit an unlawful act. ${ }^{36}$ The Urgenda case is noteworthy for its extensive discussion and justification provided by the court for giving this order, where the court argued it was not overreaching its powers and encroaching on the domain of the legislature. The court

\footnotetext{
${ }^{30} I d$. at Par. 14 and 20-23.

${ }^{31}$ Administrative Jurisdiction Division of the Council of State, ECLI:NL:RVS:2017:3156, Par. 32 (Nov. 15, 2017).

${ }^{32}$ Kabinet: einde aan gaswinning in Groningen, RIJKSOVERHEID (Mar. 29, 2018).

${ }^{33}$ Court of The Hague, ECLI:NL:RBDHA:7196 (english translation) (June 24, 2015).

${ }^{34}$ Id. at Par. 4.64-4.92.

${ }^{35}$ Supreme Court, ECLI:NL:HR:1965:AB7079 (Nov. 05, 1965).

${ }^{36}$ Court of The Hague, ECLI:NL:RBDHA:7196 (english translation), Par. 4.73 (June 24, 2015).
} 
carefully constructs a reasoning where it reiterates that it is required to enforce the law, and that legal norms drove the court to make the order to protect Urgenda against unlawful acts by the State. ${ }^{37}$ The effects of this order on the State is acceptable in the view of the court, as it does not tell the State which measures to take to achieve the goal of $25 \%$ reduction of greenhouse gas emissions, this is left to the State to decide. ${ }^{38}$

The state immediately lodged an appeal against the judgment, and the reasoning of the court of appeal is interesting because it scrutinises the decision-making of the executive in a different fashion. ${ }^{39}$ The court does not employ an (extensive) interpretation of national law but anchors its reasoning directly to the risk of the violation of articles 2 and 8 of the European Convention of Human Rights. ${ }^{40}$ The dangers of climate change are such that there is a real chance of loss of life which forces the state to act to protect its citizens from the harmful effects of climate change. ${ }^{41}$ This use of international law means that the court does not have to show deference to an administrative interpretation but can independently assess the effectiveness of the actions of the executive. The use of this mechanism might be specific to this case or herald a wider shift towards a more litigious society and activist judiciary. The state has lodged a final appeal on points of law which is yet to be determined.

\section{CONCLUSION}

Through the exploration of a landmark case this chapter has shown how the Dutch Administrative Law courts try to solve the tension between protecting the rights of citizens and the deference due to the (political) decisions of the executive. The more intense scrutiny of the powers of the executive follows a wider trend in Dutch Administrative law. This does as yet not correlate with a decrease or increase in request for judicial review rather the use of an

\footnotetext{
${ }^{37}$ Id. at Par. 4.99-4.102.

${ }^{38} I d$. at Par. 4.99-4.101.

${ }^{39}$ Court of Appeal The Hague, ECLI:NL:GHDHA:2018:2610 (english translation), (Oct. 09, 2018).

40 The right to life and the right to private and family life respectively.

${ }^{41}$ See ECLI:NL:GHDHA:2018:2610 supra note 20, at Par. 43-45.
} 
objection procedure and the increase or decrease of cost of procedures present important mechanisms in that respect.

\section{REFERENCE LIST}

A. T. Marseille \& I.M. Boekema, Administrative decision-making in reaction to a Court judgment can the administrative judge guide the decision-making process?, 9 UTRECHT LAW REVIEW (3) 51-61 (2013).

A.T. MARSEILLE ET AL., BestuURSRECHT 2 (6th ed. 2016).

B. Marseille et al., Hoger beroep in het bestuursrecht: massaal gebruik, ontevreden gebruikers, 38 RECHT DER WERKELIJKHEID (2) 76-98 (2017).

I.M. BOEKEMA, DE STAP NAAR HOGER BEROEP (2015).

J.G.VAN ERP \& C.M. KLEIN HAARHUIS, DE FILTERWERKING VAN BUITENGERECHTELIJKE PROCEDURES (Cahier 2006-6, WODC 2006).

K.J. de Graaf et al., Administrative decision-making and legal quality: An introduction, in QUALITY OF DECISION-MAKING IN PUBLIC LAW 3-10 (K.J. de Graaf, J.H. Jans, A.T. Marseille, J. de Ridder 2007).

Kabinet: einde aan gaswinning in Groningen, RIJKSOVERHEID (Mar. 29, 2018), https://www.rijksoverheid.nl/onderwerpen/gaswinning-in-

groningen/nieuws/2018/03/29/kabinet-einde-aan-gaswinning-in-groningen

K. J. de Graaf \& Albert T. Marseille, On administrative adjudication, administrative justice and public trust. Analyzing developments on access to justice in Dutch Administrative law and its application in practice, in ON LAWMAKING AND PUBLIC TRUST 103-120 (S. Comtois \& K. J. de Graaf 2016).

M. Wever \& A. T. Marseille, Neutrality and the Dutch objection procedure, 15 INTERNATIONAL PUBLIC ADMINISTRATION REVIEW 107-128 (2018).

RING et al., BESTUURSRECHT 1 (5th ed. 2016).

T. R. TYLER, WHY PEOPLE OBEY THE LAW (2006). 


\section{CASES}

Administrative Jurisdiction Division of The Council of State, ECLI:NL:RVS:2017:3156 (Nov. 15, 2017).

Court of Appeal The Hague, ECLI:NL:GHDHA:2018:2610 (english translation), (Oct. 09, 2018).

Court of The Hague, ECLI:NL:RBDHA:7196 (english translation) (June 24, 2015).

Supreme Court, ECLI:NL:HR:1965:AB7079 (Nov. 05, 1965). 


\title{
JUDICIAL REVIEW ON CONSENSUAL SOLUTIONS IN ADMINISTRATIVE MATTERS AND JUDICIAL RESPECT
}

\author{
Guilherme Calmon* \\ Estácio de Sá University, Brazil
}

Since March 2016, the Brazilian Civil Code of Procedure prescribes the execution of a mediation hearing on the disputes judicially initiated, as well as encourages conflict's consensual solutions such as conciliation and mediation, amongst others. From the work of the National Justice Board was initiated the implementation phase and the beginning of the activity of the judiciary centers of conflict's consensual resolution, ${ }^{42}$ which shall develop programs aimed to assist, orient and encourage the self-solutions. ${ }^{43}$

The Brazilian Law experiences a cultural change involving the Public Administration, especially at the federal level. The search for higher agility on the solution of disputes, the facilitation of the satisfaction of citizen's rights through small value demands (instead of public judicial certificates) and the encouragement to dispute consensual solutions - through conciliation and mediation - are aspects that show a new stage at the Brazilian judicial system on the relationships between State and the citizen.

The impact of the Judiciary management of proceedings influenced some changes on the Civil Process Code, federal law that regulates the proceeding system of rendering of judicial services on the civil sphere. The idea of access to justice has developed historically based on

\footnotetext{
* Associate Professor in Comparative Public Law in the Post-Graduate Law Program of the University Estácio de Sá / PPGD-Unesa.

${ }^{42}$ Guilherme Calmon Nogueira da Gama, Novo Código de Processo Civil e atuação do Conselho Nacional de Justiça, in 2 Reflexões sobre o nOvo Código de Processo Civil 21 (Geisa de Assis Rodrigues \& Robério Nunes dos Anjos Filho orgs. 2016).

${ }^{43}$ Código de Processo Civil, art. 165.
} 
the idea that the judicial control also impacts on administrative acts, ${ }^{44}$ as occurred with the implementation of mandatory actions (ações mandamentais), such as the writ of mandamus and the habeas corpus, besides the recently developed class actions - related to collective, general and homogeneous individual rights.

In light of the jurisdictional unity principle, the monopoly of the jurisdictional function has been assigned to the judiciary authorities, even though it is currently being questioned due to the various problems related to the effective solution of conflicts of interest. In the field of the denominated mass disputes, verified with increasing frequency, it is essential to think about the judicial proceedings that were expressly adopted on the Brazilian proceeding system, especially in relation to the notion of solutions effectiveness.

With respect to the role of the Public Administration in court, the rule is the existence of some procedural prerogatives, such as more extensive deadlines, the non-application of the rule of the formal (or false) confession, the automatic "appeal", making the proceedings against the Public Treasury slower for the effective settlement of the dispute, in addition to causing greater costs to the citizens. The dogma of the unavailability of the public interest involving conflicts with the Public Administration is currently being questioned. ${ }^{45}$

The Law no. 13.140/15 expressly initiated to contemplate the possibility for the Public Treasury to act on matters of consensual solution of conflicts with its administrated citizens. In fact, it is being a long time that extrajudicial solutions of issues involving the Government and the citizen are accepted, as in the examples of the friendly expropriation (Decree-Law n. 3.365/41) and the term of adjustment of conduct. With the Mediation Act and the new Code of Civil Procedure, there was stimulus to the search for the consensual solution, including in litigation involving the Public Administration. ${ }^{46}$

Another point that deserves attention is the need for technical and scientific qualification of certain people - as in the case of amicus curiae - to be admitted into judicial

\footnotetext{
${ }^{44}$ J. Guilherme de Aragão, A justiça administrativa no Brasil, CADERNOS DE ADMINISTRAÇÃo PúBLICA- FGV EBAP 24 (1955).

45 Marcella Araújo da Nova Brandẽo, A CONSENSUALIDAde E A ADMinistraÇÃo PÚbliCA EM JUÍzo 54 (Dissertação de Mestrado Escola de Direito da Fundação Getúlio Vargas 2009).

${ }^{46} I d$. at 63.
} 
and administrative procedures, in order to make it possible to understand the various aspects of the interests under discussion. ${ }^{47}$

In the context of the Brazilian Labor Justice, there was already the provision of the possibility of the extrajudicial conciliation to solve certain conflicts, including the use of the Union organizations for the conclusion of collective labor conventions or agreements, in the today's common idea of the correct breadth of access to justice. The long-term solution, full of formalities from judicial proceeding, can be translated into an injustice in certain events and, therefore, the constitutional amendment n. 45/2004 inserted the guarantee of the reasonable duration of the proceeding so that no more judicial demands - and, why not administrative procedures - which were eternal.

Access to justice, based on the informality of the effective solution of the conflict, through the cooperation of the subjects involved, points to the need to pay attention to the really relevant issues that are taken to the judiciary system. And, under such highlight, the contemporary judge needs to be aware of the importance of leading the parties to the friendly composition in a quick and effective manner. The procedural system should be reinterpreted under the focus of informalism in conflict resolution, through institutionalized cooperation, in the constant search for construction and effective access to justice in an expanded manner. In the United States of America, the widening of access has been made through the creation and development of Alternative dispute resolutions (ADRS), which have encompassed programs to focus on the use of extrajudicial means to solve conflicts, such such as mediation, negotiation and arbitration.

Such ideas cannot exclude issues involving the Public Administration and those administered by it, in particular in a Democratic State, in which fundamental rights gain significant importance also in the relations considered of Public Law. The use of the tools for consensus-solving methods of conflict does not represent the failure of judicial protection. On the contrary: it reinforces the role of the Justice System through a solution awarded to conflicts in cases where the consensual solution is not really possible.

\footnotetext{
${ }^{47}$ MAURo CAPPELletti \& BRyANT Garth, ACESSO À JUSTIÇA 68 (1998).
} 
It is no longer possible to maintain the idea of the perpetuation of jurisdiction in the state view as the only way to solve conflicts; on the contrary, it is important to deep in the vision concerning the solving of conflicts thorough informalism and cooperation, including with the presence of the Public Administration. There must, of course, preserve the observance of the constitutional principle of independence and harmony between the state powers, and it is certain that in exceptional situations - and duly restricted - it will be possible to exercise judicial control over the friendly compositions encompassing as one of the subject the Public Treasury. Jurisdiction is an activity monopolized by the State, but it does not monopolize the solving of conflicts.

The work to be developed points out to a new model of resolution of conflicts of interest in contemporary society, identifying appropriate and effective means to confirm the constitutional principles in order to achieve effective access to justice, even with regard to issues involving Public Administration.

\section{REFERENCE LIST}

G. C. N. da Gama, Novo Código de Processo Civil e atuação do Conselho Nacional de Justiça, in 2 REFLEXÕES SOBRE O NOVO CóDIGO DE PROCESSO CIVIL 21-58 (Geisa de Assis Rodrigues \& Robério Nunes dos Anjos Filho orgs. 2016).

J. G. de Aragão, A justiça administrativa no Brasil, CADERnOS DE ADMINISTRAÇão PÚBLICAFGV EBAP 1-46 (1955).

M. A. DA Nova BRANDÃo, A CONSENSUALIDAdE E a ADMINISTRAÇÃo PÚBLICA EM JUÍzo (Dissertação de Mestrado, Escola de Direito da Fundação Getúlio Vargas 2009).

M. CAPPElletTi \& B. GaRTh, ACESSO À JUSTIÇA (1998). 


\title{
ADMINISTRATIVE DEFERENCE IN THE UNITED STATES:
}

\section{Kisor and the Consolidation of Auer Jurisprudence}

\author{
Ilaria Di-Gioia*
}

Birmigham City University, United Kingdom

Auer deference, i.e. the extent to which courts defer to an agency's interpretation of its own ambiguous regulation, is under the spotlight in the United States.

The doctrine has been greatly criticised by both academics and judges concerned about the increase of the power of administrative agencies ${ }^{48}$ but in June 2019 the U.S. Supreme Court confirmed its constitutionality by a 5-4 majority in Kisor v. Wilkie. ${ }^{49}$ Justice Kagan authored the majority opinion and insisted that the Auer doctrine is still alive. Justice Gorsuch, on the other hand, argued in his concurrence that because of the new limitations that Kisor imposes on administrative deference, Auer has become a paper tiger, meaning that it has lost its bite and efficacy.

This abstract briefly reviews the Kisor decision and the points raised in the majority opinion. It argues that the decision has not changed the Auer doctrine but instead consolidated its technical aspects.

\footnotetext{
* Dr Ilaria Di Gioia is a Lecturer in Law. She teaches Public Law, Legal Method, American Legal Practice, the Individual and the US Constitution and Federalism and the US Constitution. She devotes her free time to public service, is her capacity of Honorary Vice-Consul for Italy in Birmingham. Dr. Di Gioia is an active member of the American Politics Group (UK), a sub-group of the Political Studies Association and has presented her research at several conferences in the UK, Europe, the US and Latin-America.

${ }^{48}$ For instance, Justice Thomas expressed discomfort with the existing deference regime and in Michigan v. EPA, argued that Chevron delegation "is in tension with Article III's Vesting Clause, which vests the judicial power exclusively in Article III courts, not administrative agencies" and in tension with Art. I "which vests "[a]11 legislative Powers herein granted' in Congress" thus advancing the case for revision of the doctrine.

${ }^{49}$ Kisor v. Wilkie, 139 S. Ct. 657 (2019).
} 
First, a few words on the facts of the case. The lawsuit involved a Marine veteran seeking appeal against the decision of the Department of Veterans Affairs (VA) to refuse him the award of retroactive disability benefits for his service-related post-traumatic stress disorder (PTSD) because the evidence provided by the claimant was, according to the VA's interpretation of its regulations, not "relevant" ${ }^{50}$ On appeal, the Federal Circuit Court found that "uncertainty in application suggests that the regulation is ambiguous" and therefore applied Auer deference affirming the VA's construction of the regulation and, as a consequence, the VA's denial of retroactive benefits. The question before the Supreme Court was whether Auer v. Robbins ${ }^{51}$ and Bowles v. Seminole Rock \& Sand Co. ${ }^{52}$ which direct courts to defer to an agency's reasonable interpretation of its own ambiguous regulation, should be overruled. Despite fears and rumours that a majority of conservative justices would have axed Auer, the Roberts Court used this opportunity to reiterate the standing of the doctrine and clarify technical issues related to the process of administrative deference. The majority did not miss the chance to defend Auer on the basis of stare decisis but this is not the main point of the decision. The significance of Kisor, in this author's opinion, lies in its consolidation of previous jurisprudence and explanation of the circumstances in which the courts should be deferring interpretation to the agencies. According to Justice Kagan, the doctrine remains "potent in its place but cabined in its scope". ${ }^{53}$ Cabined because, she explains, the courts can defer interpretation only if the following requirements are satisfied:

a) the regulation is genuinely ambiguous ${ }^{54}$

b) the agency's reading is reasonable ${ }^{55}$

c) the regulatory interpretation is authoritative, i.e. one actually made by the agency $^{56}$

\footnotetext{
${ }^{50}$ Department of Veterans Affairs' New and Material Evidence regulation.38 C.F.R. § 3.156, "A claimant may reopen a finally adjudicated claim by submitting new and material evidence". 38 C.F.R "Notwithstanding any other section in this part, at any time after VA issues a decision on a claim, if VA receives or associates with the claims file relevant official service department records that existed and had not been associated with the claims file when VA first decided the claim, VA will reconsider the claim, notwithstanding paragraph (a) of this section. ${ }^{51}$ Auer v. Robbins, 519 U.S. 452 (1997).

${ }^{52}$ Bowles v. Seminole Rock \& Sand Co., 325 U.S. 410 (1945).

${ }^{53}$ Kisor v. Wilkie, 139 S. Ct. 2400, 2408 (2019).

${ }^{54} I d$. at 2415 .

${ }^{55} \mathrm{Id}$. at 2416.

${ }^{56} \mathrm{Id}$. The interpretation must at the least emanate from those actors, using those vehicles, understood to make authoritative policy in the relevant context
} 
d) the agency's interpretation is expertise based, i.e. in some way it implicates agency substantive expertise ${ }^{57}$

e) an agency's reading of a rule in question reflects a "fair and considered judgment",58

As to point $\mathrm{A}$ and $\mathrm{B}$, these are well-established requirements and they apply to Chevron deference more generally. ${ }^{59}$

Point $\mathrm{C}$ is an attempt to consolidate jurisprudence around the distinction between authoritative interpretations and non-binding ones. The issue is particularly relevant with regards to interpretive rules and legislative rules. In Perez v. Mortgage Bankers Assn (2015), ${ }^{60}$ a unanimous court established that when a federal administrative agency first issues a rule interpreting one of its regulations, it is generally not required to follow the notice-and-comment rulemaking procedures of the Administrative Procedure Act (APA or Act) ${ }^{61}$ As a consequence, Perez confirmed that interpretive rules do not have the force or effect of law. ${ }^{62}$ On the other hand, legislative rules which impose obligations, or produce other significant effects on private interests do require the notice and comment procedure. ${ }^{63}$ Kisor confirmed the different procedural requirements for interpretive rules and legislative rules. Furthermore, in its attempt to consolidate the jurisprudence around authoritativeness of agency interpretations, it seemed to respond to Justice Scalia's concurrence in Perez regarding the role of the courts. In Perez, Justice Scalia stated that an agency can interpret its regulations, but the courts have the final say in deciding whether that interpretation is correct:

I would therefore restore the balance originally struck by the APA with respect to an agency's interpretation of its own regulations, not by rewriting the Act in order to make up for Auer, but by abandoning Auer and applying the Act as written. The agency is free to interpret its own regulations with or without notice and comment; but courts will decide - with no deference to the agency - whether that interpretation is correct. ${ }^{64}$

\footnotetext{
${ }^{57}$ Id. at 2417 (2019).

${ }^{58} I d$.

59 Before concluding that a rule is genuinely ambiguous, a court must exhaust all the "traditional tools" of construction: Chevron U.S.A. Inc. v. Natural Resources Defense Council, Inc., 467 U.S. 837, 843, n. 9, 104 S.Ct. 2778, 81 L.Ed.2d 694 (1984).

${ }^{60}$ Perez v. Mortg. Bankers Ass'n, 135 S. Ct. 1199, 1213 (2015).

615 U.S.C. $\$ 553(\mathrm{~b})(\mathrm{A})$.

${ }^{62}$ Perez v. Mortgage Bankers Assn., 575 U. S. 92,_—, 135 S.Ct. 1199, 1204, 191 L.Ed.2d 186 (2015).

63126 A.L.R. Fed. 347 (Originally published in 1995).

${ }^{64}$ Perez v. Mortg. Bankers Ass'n, 135 S. Ct. 1199, 1213 (2015).
} 
In response to Scalia's comments, Justice Kagan confirmed that interpretive rules do not have the force of law but also clarified that the meaning of legislative rules "remains in the hands of the courts":

\begin{abstract}
An interpretive rule itself never forms the basis for an enforcement action $[\ldots]$ the meaning of a legislative rule remains in the hands of courts, even if they sometimes divine that meaning by looking to the agency's interpretation. Courts first decide whether the rule is clear; if it is not, whether the agency's reading falls within its zone of ambiguity; and even if the reading does so, whether it should receive deference. In short, courts retain the final authority to approve — or not—-the agency's reading of a notice-and-comment rule. ${ }^{65}$
\end{abstract}

As to point $\mathrm{D}$, expertise of the agency is a foundational requirement for Auer because, Justice Kagan explains, administrative knowledge and experience largely "account [for] the presumption that Congress delegates interpretive lawmaking power to the agency." ${ }^{\prime 66}$ In other words, expertise is the reason why we assume that Congress delegated interpretation; if the agency does not have expertise there is no presumption of delegation.

In regards to point E, deference to "fair and considered judgement", courts are required to assess whether the agency interpretation is fair and does not creates "unfair surprise" to regulated parties. ${ }^{67}$ Justice Kagan explains: "we have therefore only rarely given Auer deference to an agency construction "conflict[ing] with a prior" one. ${ }^{68}$ Again, the court is inclined to maintain certainty of the law; it does not innovate but cites to previous judgements in an attempt to strengthen jurisprudence.

Kisor is certainly not the revolutionary decision that many were expecting. Instead, this abstract argues, it is an exercise in doctrine consolidation. Time only will tell whether the consolidation of the doctrine is real or only another temporary block to the predicted decline of administrative deference in the United States.

\footnotetext{
65 Supra note 6 at 2400, 2420 (2019).

${ }^{66}$ Id. at 2417 (2019), citing to Martin v. Occupational Safety and Health Review Com'n , 499 U.S. at 153,111 S.Ct. 1171.

${ }^{67}$ Long Island Care Long Island Care at Home, Ltd. v. Coke, 551 U.S. 158 at 170, 127 S.Ct. 2339 (2007).

${ }^{68}$ Supra note 6 at 2400, 2418 (2019) citing Thomas Jefferson, 512 U.S. at 515, 114 S.Ct. 2381.
} 


\section{REFERENCE LIST}

126 A.L.R. Fed. (Originally published in 1995).

5 U.S.Code $\S 553(b)(A)$.

\section{CASES}

U.S. Supreme Court, Auer v. Robbins, 519 U.S. 452 (1997).

U.S. Supreme Court, Bowles v. Seminole Rock \& Sand Co., 325 U.S. 410 (1945).

U.S. Supreme Court, Chevron U.S.A. Inc. v. Natural Resources Defense Council, Inc., 467 U.S. 837, 843, n. 9, 104 S.Ct. 2778, 81 L.Ed.2d 694 (1984).

U.S. Supreme Court, Kisor v. Wilkie, 139 S. Ct. 2400, 2420 (2019).

U.S. Supreme Court, Kisor v. Wilkie, 139 S. Ct. 657 (2018).

U.S. Supreme Court, Long Island Care Long Island Care at Home, Ltd. v. Coke, 551 U.S. 158, 127 S.Ct. 2339 (2017).

U.S. Supreme Court, Martin v. Occupational Safety and Health Review Com'n , 499 U.S. at 153, 111 S.Ct. 1171.

U.S. Supreme Court, Perez v. Mortg. Bankers Ass'n, 135 S. Ct. 1199, 1213 (2015). 


\title{
JUDICIAL DEFERENCE \& RIGHT TO A FAIR TRIAL:
}

\author{
A feasible conciliation in Latin America?
}

\author{
Ricardo Perlingeiro*
}

Estácio de Sá University, Brazil

\begin{abstract}
Congress is the font of democratic legitimacy in the nation's traditional constitutional theory. And courts are the traditional model for legitimate decision-making in the mind of the legal profession, in which most law professors are socialized. [...] we cannot trust the administrative authorities themselves and must rely instead on officials external to the bureaucracy - that is, elected lawmakers and life-tenured judges. Thus 'administrative law' has been largely synonymous with external constraints - statutory and especially judicial - on administrative action.

According to Jerry Mashaw's theory it is a mistake. We are not wrong in our aspiration to subject government to law. But we are wrong to think that exacting statutory commands and judicial review are the means to fulfill that aspiration. [...] An administrative authority, under the right conditions, can self-generate law from within - and do it far better than elected lawmakers or courts can. ${ }^{69}$
\end{abstract}

The excessive litigation in Latin America is mainly attributable to administrative law cases (tax and social security matters) as well as cases of private law subject to regulation by agencies, such as telecommunications services and supplementary health care. The astounding backlog of pending court claims (nearly 50 million in Brazil $)^{70}$ is symptomatic of a judicial system on the verge of collapse. Under the pretext of protecting fundamental rights, the Latin America court system constantly advances into typically executive and legislative functions.

My research on judicial deference towards administrative authorities includes a comparative study of contemporary models of administrative justice. This approach attempts to contribute to the debate on the concept and scope of judicial deference, which is traditionally linked with the idea of separation of powers and based on the notion that certain questions

\footnotetext{
* Associate Professor in Comparative Public Law in the Post-Graduate Law Program of the University Estácio de Sá / PPGD-Unesa.

${ }^{69}$ Nicholas R. Parrillo, Jerry L. Mashaw creative tension with the field of administrative law, in 2 ADMINISTRATIVE LAW FROM THE INSIDE OUT 5 (Nicholas R. Parrillo ed., 2017).

${ }^{70}$ CONSElho Nacional de JustiçA, JustiçA EM NúmEROS 2017 [Justice in Numbers 2017] (2018).
} 
referred to the administrative bodies are too technically complex to be reviewed by the ordinary courts. ${ }^{71}$ By the way, those basic ideas on judicial deference are made clear by US/UK law but are not always apparent in the legal systems of French origin, including those of Latin America. Moreover, it is sometimes forgotten that judicial deference, as it is currently understood, especially in US/UK law, grew out of notion of "the due process clause", which is binding not only on the courts but also on other public authorities. ${ }^{72}$

According to the Inter-American Court of Human Rights, one of the dimensions of the fundamental human right to effective protection in administrative law cases is the "intensity of review of both the form and content of administrative decisions". ${ }^{73}$ This protection should be complete and the review of procedural and substantive legality should include, where appropriate, verification that the administrative authority did not exceed its discretionary powers. $^{74}$

In any case, all over the world, administrative justice is based on either of two models, the one of English, the other of French origin. The French model is a system divided into courts of general jurisdiction, on the one hand, and specialized administrative courts with full powers of review of administrative acts, on the other. In common-law countries, the models of administrative justice tend to have only generalist courts with limited powers of review, which refrain from examining certain aspects of administrative acts; nevertheless, due process is ensured through adjudication conducted by administrative tribunals or administrative bodies endowed with quasi-judicial powers ${ }^{75}$.

Due process in the administrative sphere is therefore a constitutional prerequisite for courts to exercise only limited review of administrative decisions, since it ensures that citizens will not be deprived of their human right to (independent, impartial and qualified)

\footnotetext{
${ }^{71}$ Guobin Zhu, General report on deference to the administration in judicial review, in 20TH INTERNATIONAL CONGRESS OF COMPARATIVE LAW, International Academy of Comparative Law, Fukuoka (July 2018).

${ }^{72}$ Omar T. McMahon, A fair trial before quasi-judicial tribunals as required by Due Process, 29 MARQ. L. ReV. 95 (1946).

${ }^{73}$ Case of Barbani Duarte et al. v. Uruguay, InTER-AMERICAN Court OF Human Rights (Oct. 13, 2011), para 204.

${ }^{74}$ Articles 3 and 4 of the Euro-American model code of administrative jurisdiction. RICARDO PERLINGEIRO \& Karl-Peter Sommermann, Euro-American Model Code of Administrative Jurisdiction 7, 8 (2014).

${ }^{75}$ See Peter Cane, Por que ter tribunais administrativos? [Why have administrative tribunals?], 17 A\&C Revista De Direito Administrativo \& Constitucional (69) 77-110 (July/ Sept. 2017).
} 
adjudication. ${ }^{76}$ To prevent unnecessary duplication of adjudication and government spending, only part of the disputes will be reallocated from the courts to other spheres of power. As Michael Asimow explains in his article Five Models of Administrative Adjudication, ${ }^{77}$ the implementation of due process in the administrative phase will naturally tend to increase judicial deference to the authorities, thereby reducing the caseload of the courts.

Due process in the administrative sphere is guaranteed by the constitutions of Brazil, Colombia, Ecuador, Nicaragua, the Dominican Republic and Venezuela, and by the legislation of Argentina, Bolivia, Peru and Uruguay. Nevertheless, in Latin America, such (extrajudicial) procedural guarantees are still in the implementation phase, because Latin American administrative bodies, culturally influenced by their Continental European origins, are not in keeping with the exercise of quasi-judicial powers by administrative authorities. For instance, in Brazil, the only administrative body with quasi-judicial powers is the maritime tribunal, as recognized by the Federal Supreme Court in its precedent of $1934 ;{ }^{78}$ since then, there has never been any further discussion on the subject. In reality, for the time being, the extrajudicial administrative [dispute-resolution] proceeding in Latin America does not fulfill its role of settling disputes but "is merely an attempt to draw water from a dry well". ${ }^{79}$

Moreover, Michael Asimow's hypothesis still needs to be demonstrated on the Latin American legal scene, i.e., it needs to be confirmed that the implementation of due process in the administrative sphere would reduce review by the courts, as is traditionally observed in the models of English origin. If not, it would merely result in a duplication of spending and adjudication, which, in Latin America, would amount to the duplication of millions of cases.

In other words, instituting due process in the administrative phase in Latin American countries would be justifiable only if it automatically entailed judicial deference, which is not so obvious in those countries. It should also be borne in mind that mutual confidence between

\footnotetext{
76 See Jerry L. Mashaw, DuE PROCESS In the Administrative StATE (1985). On the lack of need for a robust doctrine of judicial deference in countries where administrative authorities do not have the power to adjudicative, see John C. Reitz, Deference to the administration in judicial review, 66 THE AMERICAN JOURNAL OF COMPARATIVE LAW (1) 297-298 (2018).

${ }^{77}$ Michael Asimow, Five models of administrative adjudication, 63 Ам. J. ComP. L. 3 (2015).

${ }^{78}$ STF, Agravo de Instrumento 11.094, Report by Justice Bento de Faria (May 28, 1934).

79 Juan Carlos Cassagne, El procedimiento administrativo y el aceso a la justiciar [Administrative procedure and access to the justice system], in Tendencias ACtuales Del Procedimiento Administrativo EN LATINOAMÉRICA Y Europa [Current Trends In Administrative Procedure In Latin America And Europe] 53, 75 (Pedro Aberastury \& Hermann-Josef Blanke eds. 2012).
} 
courts and administrative institutions, and especially the citizens' confidence in administrative bodies, is a factor that must be taken into account in the characterization of judicial deference.

Yet the subject matter of this study will go beyond the difficulties experienced in Latin America. An equally important question is whether the creation of administrative due process resulting in the limitation of the courts' powers of review would in fact only shift the problem, that is to say, whether part of the claims would simply be withdrawn from the courts and transferred to other spheres of authority without reducing the high level of litigiousness (which is the result that has been observed in both the USA and United Kingdom in the case of the "administrative law judges" and the administrative tribunals. ${ }^{80}$ The executive duties (or administrative functions of implementation) falling within the competence of the administrative authorities must not be left out of the equation, because it is the faulty performance of such duties that is the root cause of individual complaints against the administrative bodies.

One might therefore ask whether it is really justifiable to spend public funds to implement due process in the administrative phase since, in practice, it merely shifts administrative conflict resolution from the courts to other bodies with quasi-judicial powers? Is that the purpose of judicial deference and closed judicial review in contemporary administrative justice? Judicial deference that merely withdraws claims from the courts, or that withdraws them both from the courts and from any other adjudicative body? And what if that happened? Would preliminary due process also be admissible for initial administrative decisions (frontline decisions)? If so, to what extent?

In this context, my research objectives are (1) to identify parallels and contrasts between theoretical approaches of judicial deference to administrative decisions in the UK, US, and Latin America [not only to administrative adjudication decisions, but also to front-line administrative decisions]; (2) to explain the various legal arguments in favor of deference and to correlate them with the corresponding constitutional theories, especially regarding the due process clause; (3) to contribute to the understanding of the theoretical foundations of judicial deference and to present recommendations for the use of such deference.

\footnotetext{
${ }^{80}$ See Daniel Lee Feldman, Administrative agencies and the rites of due process: Alternatives to excessive litigation, 7 FORDHAM URB. L.J. 229 (1978).
} 


\section{REFERENCE LIST}

CONSElho NACiOnAl de JustiçA, Justiça EM NúMERos 2017 [Justice in Numbers 2017] (2018).

D. L. Feldman, Administrative agencies and the rites of due process: Alternatives to excessive litigation, 7 FORDHAM URB. L.J. 229-252 (1978).

G. Zhu, General report on deference to the administration in judicial review, in 20TH INTERNATIONAL CONGRESS OF COMPARATIVE LAW, International Academy of Comparative Law, Fukuoka (July 2018).

J. L. Mashaw, Due PROCESS IN THE AdMinisTRATIVE StATE (1985).

J. C. Reitz, Deference to the Administration in Judicial Review, 66 THE AMERICAN JOURNAL OF COMPARATIVE LAW (1)297-298 (2018).

J. C. Cassagne, El procedimiento administrativo y el aceso a la justiciar [Administrative procedure and access to the justice system], in TENDENCIAS ACTUALES DEL PROCEDIMIENTO ADMINISTRATIVO EN LATINOAMÉRICA Y EUROPA [Current Trends In Administrative Procedure In Latin America And Europe] 53-75 (Pedro Aberastury \& Hermann-Josef Blanke eds. 2012).

M. Asimow, Five models of administrative adjudication, 63 АM. J. CoMP. L. 3-32 (2015).

N. R. Parrillo, Jerry L. Mashaw creative tension with the field of administrative law, in 2 AdMINISTRATIVE LAW FROM THE Inside OuT 5 (Nicholas R. Parrillo ed., 2017).

O. T. McMahon, A fair trial before quasi-judicial tribunals as required by Due Process, 29 MARQ. L. REV. 95-107 (1946).

P. Cane, Por que ter tribunais administrativos? [Why have administrative tribunals?], 17 A\&C

- REvista de Direito Administrativo \& ConstituCiOnAl (69)77-110 (July/ Sept. 2017).

R. Perlingeiro \& K.-P. Sommermann, Euro-American Model Code of Administrative JURISDICTION (2014).

\section{CASES}

Inter-American Court of Human Rights, Case of Barbani Duarte et al. v. Uruguay (Oct. 13, 2011), para 204.

Supremo Tribunal Federal, Agravo de Instrumento 11.094, Report by Justice Bento de Faria (May 28, 1934). 


\title{
JUDICIAL DEFERENCE AND PUBLIC POLICY:
}

\author{
Respecting the boundaries
}

\author{
Vanice Lírio do Valle* \\ Estácio de Sá University, Brazil
}

\section{INTRODUCTION}

Judicialization of the politics is a widespread phenomenon, challenging judges and academics to draw a model of judicial scrutiny capable to balance human rights enforcement and separation of powers. Deference to public choices embodied into administrative law is one of the available tools to provide that balance. The concept is not new, with distinct experiences in various countries - and Brazil is no exception.

Despite thirty years of a Constitution promulgated in a newly redemocratized ambience, the idea of a deferential approach is still associated with an unintended constraint to judicial review - therefore, as a violation of the checks and balances principle. On the other hand, Brazil face a growing tendency to judicialization, especially in the socioeconomic rights field. The result is a growing judicial interference in public policies, with an unclear scrutiny frame.

This paper examines specifically to the application of deference as judicial criteria in conflicts related to administrative law concerning the design and implementation of public policies. The problem is particularly relevant in Brazil, due to a growing phenomenon of judicialization of social rights, usually regulated only in the administrative realm.

Departing from an historical contextualization that explains why the deferential approach entered in disfavor, the paper explores a theoretical frame that enables judicial review, 
without discarding that administrative choices are based in specific institutional capacities. Through a descriptive-analytical methodology, it proposes a content to judicial deference that requires disclosure of the administrative reasoning in the deliberation under scrutiny, valuing a procedural dimension when it comes to public choices. Substantive criticism may be consider by the Judiciary, but only in a dialectical relation with the motivations informed by Public Administration.

Rescuing deference to administrative choices according to the proposed scope is a relevant alternative to prevent Judiciary from entering a swampy field, replacing public choices that should be hold by other agents.

\section{HOW THE DEFERENTIAL APPROACH ENTERED IN DISFAVOR IN THE BRAZILIAN LEGAL} COMMUNITY

Pressed by conservative forces of the elite who feared a left-wing dictatorship, the military assumed power in Brazil - some will say reluctantly ${ }^{81}$ - enacting nine days after the revolution, an "Institutional Act" 82 altering the 1946 Constitution.

As tension grows in the country, that first initiative reveals to be insufficient. The military repeated the strategy of twisting the constitution by successive "Institutional Acts", which imposed severe limitations on the federal organization of the country, as well as the political and civil liberties of the population. ${ }^{83}$

\footnotetext{
* Visiting Fellow at the Human Rights Program, Harvard Law School. Post-doctorate at the Brazilian School on Public Administration - EBAPE/FGV. Doctorate in Public Law at Gama Filho University. Permanente Professor at Estacio de Sá University (Rio de Janeiro).

${ }^{81}$ R.D. Evans, The Brazilian revolution of 1964: Political surgery without anaesthetics, 44 INTERNATIONAL AFFAIRS (Royal Institute of International Affairs 1944-) (2), 267-281 (Apr. 1968).

82 The "institutional acts" were enacted at the time by the Executive, and reformulate partially the constitutional text without observing the formal procedure required to the approval of a constitutional amendment. There were seventeen institutional acts enacted during the dictatorship, mostly to centralize power in the Executive branch, ceasing individual liberties, and reducing legislative power and prerogatives.

83 Roberto Gargarella, Latin American Constitutionalism: Social Rights and the "Engine Room" of the Constitution, 4 Notre DAME J. INT'L COMP. L. 9, 10-16 (2014) (reporting the historical process through which social rights were included in Latin America constitutions - without the necessary adaptation in the institutional dimension of those same countries).
} 
At the time, one could distinguish two distinct kinds of administrative choices: the ones entirely designed by law, with no space for political deliberation from public officials; and the discretionary ones - in which a broad spectrum of alternatives is grant to the decider. In the last case - discretionary administrative acts - judicial scrutiny was not allowed, according to an understanding that this will violate the checks and balances principle.

A major canon that represented that idea was that "the merit" (meaning, the political choice) of the administrative act could never be scrutinized by the Judiciary, that should be deferent to the Executive decision. Deference, therefore, was associated with a definitive blockage to judicial review, and was applied as a shield, protecting very questionable choices held during those dark times.

Power change hand in 1985, with the election by the still-existing Electoral College of Tancredo Neves, who represented democratic and progressive political forces at the time. Tragically, Tancredo Neves faced illness and was unable to take the Presidency. Hospitalized in March $14^{\text {th }}, 1985$, he died in April, $21^{\text {st }}$ of that same year, leaving as President, José Sarney - an politician clearly aligned with the previous conservative political forces. This was one of the reasons to summon a National Constituent Assembly (NCA), in which conservative and progressive representation, strongly polarized, tried to achieve minimum consensus. ${ }^{84}$

After an agitated constitutional process, the Constitution was enacted in October $5^{\text {th }}$, 1988. The absence of a prevailing political representation in the National Constituent Assembly contributed to a somehow disjointed text, in which very different tendencies searched for accommodation. That lack of coordination is deepened by recurrent constitutional amendment - there are already ninety-nine of then up to August 2019.

Despite the political disarray in the constitutional drafting, the text initiated with a sound commitment with fundamental objectives, all of them emanating from human dignity as a core idea. This is the trigger to a new understanding when it comes to judicial review of administrative action. After all, if the fundamental objectives of the Brazilian state are express in the Constitution, administrative action is always subject to an analysis about its alignment

\footnotetext{
${ }^{84}$ Gary M. Reich, The 1988 Constitution a decade later: Ugly compromises reconsidered, 40 J. INTERAM. STUD. WORLD 5, 6 (1998) (reporting some of the dynamics that happened between the political forces during the Brazilian Constituent Assembly).
} 
with those same purposes. Therefore, there could be no administrative act or decision, entirely exempt of judicial review.

The Constitution itself endorses that new perspective, as long as it provides a wide range of procedural devices in which judicial review of administrative choices can happen. ${ }^{85}$ Considering an ambience of regained political freedom, it was just natural that the legal community rejected the deferential approach as outlined during the dictatorship period. As usual in reactive periods, the Judiciary assume the opposite orientation, granting no deference at all to administrative bodies and choices, engaging in a deep scrutiny of every aspect of Executive decisions. That strategy was clearly predominant in the realm of judicial review on fundamental rights violations.

\section{CONSTITUTIONAL FRAMEWORK IN FUNDAMENTAL}

\section{RIGHTS AND THE JUDICIALIZATION OF POLITICS}

The Brazilian constitution contains an extensive list of human rights. Aside from proclaiming that the Republic grounds in human dignity (among other core values); the Brazilian constitution establishes fundamental objectives as to build a free, just and solidary society, eradicate poverty and promote the well-being of all. Those nucleus clauses derived in an extended list of human rights, including socioeconomic ones, all of them provided by an express constitutional clause, with immediate application. ${ }^{86}$ This is the result of a political strategy held by the progressive forces in the National Constituent Assembly. Constitutional clauses granting social rights with immediate application should promote a transformative agenda to be carry out by Congress, bringing social inclusion.

That transformational process, according to the Constitution itself, requires massive legislative deliberation. Clearly inspired in the Portuguese doctrine of the "constitutional

\footnotetext{
${ }^{85}$ K.S. Rosenn, Judicial review in Brazil: Developments under the 1998 Constitution, 7 Sw. JL \& TRADE AM., 291 (2000).

${ }^{86}$ Vanice Regina Lírio do Valle, Enforcing socio-economic rights through immediate efficacy: A Case study of Rio de Janeiro's right to housing, 25 TUL. J. INT'L \& COMP. L., 1 (2016).
} 
dirigisme" ${ }^{, 87}$, the Brazilian constitution, in turning concrete its general provisions, required in its original text the enactment of 285 ordinary statues and 41 complimentary laws. ${ }^{88}$ Summoning the Legislative to such a task was a clear reaction to the end of the dictatorship period. Nevertheless, building minimum consensus in Parliament around a wide variety of topics is never an easy task, especially when among them you find the distributive deliberations inherent to the grant of socioeconomic rights.

When it comes to human rights, Parliament's inertia will not authorize the nonenforcement due to the immediate efficacy clause. It was a difficult crossroad. Separation of powers required the preservation of legislative's realm of deliberation - but that solution would result in ineffectiveness of those rights. The answer was to mitigate separation of powers concerns, acknowledging room to administrative deliberation in designing public policies. Administrative law will grow as a relevant tool in promoting social rights. Frequently, whenever a lawsuit is filled, administrative regulation will be the only parameter a judge will have to decide.

Here is the point in which recent history took its toll. Administrative law was accept as means to regulate and promote socioeconomic right, in face of legislative inertia. However, the Brazilian society in general, haunted by a three-decade dictatorship, was still suspicious about the Executive, and the fairness of its deliberations. Deference to administrative law sounded as abdicating from legitimacy brought by representation when it comes to public choices. Separation of powers is revalued as an obstacle to judicial deference. Administrative law is backed in order to provide application to human rights - but always subject to broad judicial review. Despite the internal incoherence in that understanding, this is why deference was almost abandon as criteria in Brazilian Courts.

\footnotetext{
${ }^{87}$ Manoel Gonçalves Ferreira Filho, Fundamental aspects of the 1988 Constitution, in PANORAMA OF BRAZILIAN LAW 11 (Jacob Dolinger \& Keith S. Rosenn eds., 1992).

${ }^{88}$ Keith S. Rosenn, Brazil's new constitution: An exercise in transient constitutionalism for a transitional society, 38 Aм. J. CoMP. L. 773, 778 (1990).
} 


\section{RESCUING THE DEFERENTIAL APPROACH}

Judicial deference to administrative decisions is still controversial - but it is undeniable that broad scrutiny is an understanding that overburden the Judiciary, with a serious potential to preclude its adequate functioning. In complex and accelerated times, exercising the Executive function requires much distinct expertise, reinforcing the idea that institutional capacities should be take into account. This is an idea that favors deference. On the other hand, the reviewing possibility when it comes to power decisions is a historical achievement, and should not be neglect.

The possible balance between those two compelling arguments should be find in turning the deferential approach not a blockage to judicial scrutiny - but a requirement for deepening the understanding of the procedure and reasons adopted by the Administration in deciding.

According to that proposal, judicial deference in Brazil should involve a three-step approach. First, judges should inquire about the existence and content of the public policy discussed in the lawsuit. Public administration, therefore, should be capable to present its own planning on the matter, and the rationality that oriented that same public choice. The second step involves checking if the public policy is implement according to plan - or if there was any kind of change or adjustment.

These two steps are instrumental to the recognition that the particular institutional capacity that substantiate deference to administrative decisions was rightly exercise in the matter under scrutiny.

The last step would be requiring from the plaintiff that challenges the Executive decision, a necessary dialectic with the justification presented by Public Administration to its own choices. Ruling about a previous choice taken by Public Administration will be the result of an intellectual operation that take into account the initial rationale, testing its reasonableness with the counter argument presented by whomever challenged the public policy. 
The core idea in that last step is that the balance between separation of powers and institutional capacities can be achieve through a differentiated burden of justification. This cannot happen if criticism against the administrative decision abstracts from the Administration's reasons. Allowing that judicial scrutiny happens without that dialectic would abdicate the educational potential that a lawsuit can always held when it comes to a better understanding about the Executive duties and constraints.

The central proposition is that judicial deference to administrative choice is still a useful tool - as long as it relies in a known and reasonable justification on the administrative choice, considering the available options. This is a natural development of the strengthening of a democratic society.

\section{REFERENCE LIST}

G. M. Reich, The 1988 Constitution a decade later: Ugly compromises reconsidered, $40 \mathrm{~J}$. INTERAM. STUD. WORLD 5-24 (1998).

K. S. Rosenn, Brazil's new constitution: An exercise in Transient Constitutionalism for a Transitional Society, 38 AM. J. CoMP. L. 773-802 (1990).

K. S. Rosenn, Judicial review in Brazil: Developments under the 1998 Constitution, 7 Sw. JL \& TRADE AM., 291-319 (2000).

M. G. Ferreira Filho, Fundamental aspects of the 1988 Constitution, in PANORAMA OF BRAZILIAN LAW 11-25 (Jacob Dolinger \& Keith S. Rosenn eds., 1992).

R.D. Evans, The Brazilian revolution of 1964: Political surgery without anaesthetics, 44 INTERNATIONAL AFFAIRS (Royal Institute of International Affairs 1944-) (2), 267-281 (Apr. 1968).

R. Gargarella, Latin american constitutionalism: Social rights and the "engine room" of the Constitution, 4 NOTRE DAME J. INT'L COMP. L. 9-18 (2014).

V. R. Lírio do Valle, Enforcing socio-economic rights through immediate efficacy: A Case Study of Rio de Janeiro's Right to Housing, 25 TUL. J. INT'L \& COMP. L., 1-44 (2016).

Submetido em: 17/07/2019

Aceito em: 05/08/2019 